\title{
Turizm, Ulaşım ve Sosyal Medya Etkileşimi: Doğu Ekspresi ve Kars'taki Konaklama İşletmelerine Yönelik Bir Araştırma
}

\author{
Gülçin ÖZBAY \\ Sakarya Uygulamalı Bilimler Üniversitesi, Turizm Fakültesi, Gastronomi ve Mutfak Sanatları Bölümü, Sakarya \\ gozbay@subu.edu.tr \\ ORCID ID: https://orcid.org/0000-0002-5647-7137 \\ Ayça ÇEKIN \\ Sakarya Uygulamalı Bilimler Üniversitesi, Turizm Fakültesi, Turizm İşletmeciliği Bölümü, Sakarya \\ aycacekin@gmail.com \\ ORCID ID: https://orcid.org/0000-0002-1434-0781
}

Araştırma Makalesi

DOI: $10.31592 /$ aeusbed.646499

Geliş Tarihi: 13.11.2019

Revize Tarihi: 23.02 .2020

Kabul Tarihi: 25.02 .2020

\section{Atıf Bilgisi}

Özbay, G. ve Çekin, A. (2020). Turizm, ulaşım ve sosyal medya etkileşimi: doğu ekspresi ve kars’taki konaklama işletmelerine yönelik bir araştırma. Ahi Evran Üniversitesi Sosyal Bilimler Enstitüsü Dergisi, 6(1), 327-344.

ÖZ

Teknolojik gelişmeler ve bu gelişmelerin ulaşım türlerine yansımalarıyla destinasyonlardaki turizm faaliyetlerinde hareketlilik yaşanmaktadır. Online platformlar ise tüketiciler için haber kaynağı ve satın alma karar sürecinde etkiye sahip önemli bir faktör olarak değerlendirilmektedir. Ucuzluk ve güvenlik nedeniyle tercih edilen demiryolu ulaşımı içinde Doğu Ekspresi sosyal medya ve kitle iletişim araçları aracılığıyla adını sıkça duyurmaktadır. Çalışmada turizm, ulaşım ve sosyal medya etkileşiminin kavramsal olarak açıklanması, Doğu Ekspresi ve Kars’taki konaklama işletmelerine etkisinin belirlenmesi amaçlanmıştır. Ekspres yolcularına anket uygulanmış ve Kars'taki turizm faaliyetlerine etkisini belirlemek üzere konaklama işletmelerinin yöneticileriyle yarı yapılandırılmış mülakat gerçekleştirilmiştir. Katılımııların \%91'inin turistik amaçlı seyahat ettikleri, tur şirketi aracılığıyla seyahate katıldıkları, Kars’ta ortalama kalış sürelerinin 1-3 gün aralığında olduğu tespit edilmiştir. Araştırma sonuçlarına göre; katılımcıların \%51'i Doğu Ekspresi'ni ilk kez sosyal medyadan öğrendiğini, \%62'si ise 2016 y1lı sonrasında duyduğunu belirtmiştir. Konaklama işletmeleriyle yapılan mülakatlardan elde edilen bilgilerle; Doğu Ekspresi'nin işletme doluluk oranlarını yükselttiği, il turizmine katkı sağladığı, istihdamı artırdığı, ekonomiyi canlandırdığı ve yöresel ürünlerin tanıtımına daha fazla önem verilmesine sebep olduğu sonucuna ulaşılmıştır.

Anahtar Kelimeler: Doğu Ekspresi, ulaşım, demiryolu ulaşımı, sosyal medya, Kars.

\section{Tourism, Transportation and Social Media Interaction: A Research on Eastern Express and Accommodation Businesses in Kars}

\begin{abstract}
Due to technological developments and the reflections of these developments on the types of transportation, tourism activities in the destinations are experiencing mobility. Online platforms, on the other hand, are considered as a source of news for consumers and an important factor that has an impact on the purchasing decision process. The Eastern Express makes its name frequently via social media and mass media within the preferred rail transport for reasons of cheapness and safety. The aim of the study is to explain the interaction of tourism, transportation and social media conceptually and to determine Doğu Express and it's impact of the accommodation businesses in Kars. A questionnaire was applied to the Express passengers and a semistructured interview was conducted with the managers of the accommodation besinesses to determine the impact of the tourism activities in Kars. It was determined that $91 \%$ of the participants traveled for touristic purposes, participated in the trip through the tour company, and their average stay in Kars was in the range of 1-3 days. According to the research results; $51 \%$ of respondents said they had learned the Eastern Express from social media for the first time, while 62\% said they had heard it after 2016. With the information obtained from the interviews with the hospitality businesses, it was concluded that the Eastern Express increased the occupancy rates, contributed to the provincial tourism, increased employment, revived the economy and caused more attention to the promotion of local products.
\end{abstract}

Keywords: Eastern Express, transportation, railway transportation, social media, Kars.

\section{Giriş}

Turizm, insanların normal çalışma ve ikamet yerlerinin dışındaki yerlere geçici olarak taşınması, bu yerlerde kaldıkları süre boyunca yapılan faaliyetler ve onların ihtiyaçlarını karşılamak 
için oluşturulan tesisleri ifade etmektedir (Cook, Yale ve Marqua, 1999). Bunun yanı sıra turizm, arka arkaya bir yıldan fazla olmamak üzere, normal ortamlarının dışında kalan yerlere seyahat eden ve kalan kişilerin faaliyetleri olarak da tanımlanmaktadır (Page, 2009). Kişilerin yaşadıkları ve çalıştıkları yerler dışına gidebilmeleri için de ulaşım faaliyetlerini gerçekleştirmeleri gerekmektedir.

Kökeni Latin bir kelime olan "ulaşım” (transport / transportation), trans (“across" bir yerden başka yere) ve portare ("to carry" taşımak/götürmek) kelimelerinin birleşimi ile oluşmuştur. İngilizcede; "transport", "transportation" kelimeleriyle ifade edilen ulaşım (Yardımcıoğlu, 2013), "insanların, malların, haberlerin ulaşmasını sağlayan işlerin ve araçların tümü” şeklinde açıklanmaktadır (Saatçioğlu, 2011). Ulaşım, zaman ve mekân içinde, kişinin veya eşyanın yer değiştirmesine dayanan bir sistem; toplumun ihtiyaç duyduğu bir ara hizmet olarak da tanımlanmaktadır (Yardımcıoğlu, 2013). Bu ara hizmet ise birçok sektörün ve genel ekonomik yapının hareketliliği için kilit rol üstlenmektedir.

İnsanların, bir mekâna, diğer insanlara veya eşyalara erişimi sosyal ve ekonomik refah bakımından önem arz etmektedir. Ulaşım sektörü ekonomiyi hem etkilemekte hem de doğrudan etkilenmektedir. Ayrıca bu sektör ekonomiyi, istihdam oluşturma biçimiyle doğrudan, bölgesel gelişmeyi sağlamasıyla da dolaylı olarak etkileyen konumundadır (Cirit, 2014). Ulaştırma sektörü, ekonomik ve toplumsal refahı etkileyen süreçlerde rol alması sebebiyle ülke ekonomilerinin başta gelen sektörlerinden birisidir. Bundan dolayı ulaşım ile ilgili konular ülke yöneticileri ve bilim insanları için önem arz etmektedir (Saatçioğlu, 2011). Bunun yanı sıra gelişmiş ekonomilerde taşımacılık faaliyetleri katma değer ve istihdamın yaklaşık \%5'ini oluşturmaktadır. Gelişen ve gelişmekte olan ekonomilerde bu payın daha düşük olmasına rağmen, artan gelir ve altyapı gelişimi nedeniyle gelecek yıllarda çok daha hızlı bir artış göstermesi beklenmektedir (Beltrán Esteve ve Picazo Tadeo, 2015). Altyapı gelişiminde ve dolayısıyla turistik faaliyetlerin gelişiminde ulaşım türleri farklı etki düzeylerine sahiptir. Bu nedenle ulaşım türlerinin ayrı ayrı ele alınması gerekmektedir. Çalışmada demiryollarının dünyada ve Türkiye'de gelişim süreci açıklanmış, Kars ilinin turizm potansiyeli değerlendirilerek Doğu Ekspresi'ne ilişkin bilgi verilmiştir. Araştırma yöntemi açıklanarak Doğu Ekspresi yolcularına ve Kars'taki konaklama işletmelerine ilişkin bulgular ayrı başlıklar altında incelenmiştir.

Ulaştırmada meydana gelen teknolojik yenilikler seyahat süresini, hızını ve konfor seviyesini değiştirerek turizm endüstrisinde gelişmelere sebep olmuştur. Demiryolunun tanıtımı modern turizm anlayışının temelini oluşturmuş, ardından bölgeler ve bölgeler arası turizm tarzını değiştiren otomobil devrimi yaşanmıştır. Sonrasında ise ulaşılamayan yerlerde turizme olanak sağlayan uzun mesafeli hava taşımacılığındaki yeniliklerle uluslararası turizm mümkün hale gelmiştir (Truong ve Shimizu, 2016). Bu gelişmelere bağlı olarak Turizm Taşımacılık Sistemi kavramı ortaya çıkmış ve "turizm merkezlerine, tatil yerlerine yolcu ve yük akışları ile varış yerlerine giriş ve çıkış akışları arasındaki etkileşimi, ulaşım modları, yolları ve terimleri arasındaki ilişki ve bunların etkileşimi” şeklinde tanımlamıştır (Alkheder, 2016).

Turizm, ekonomik bir faaliyet olarak yüksek talep esnekliği düzeyi ile karakterizedir ve talep maliyet dalgalanmalarından büyük ölçüde etkilenmektedir. Uluslararası ve hatta ulusal ulaşım altyapılarında talep, verimli, hızlı ve ucuz bir şekilde taşınması gereken çok sayıda insan anlamına gelmektedir. Dolayısıyla büyük yatırımlar ve karmaşık organizasyonlar gerektirmektedir (Rodrıgue, Comtois ve Slack, 2017). Gelişen turizm endüstrisinde birçok ulaştırma parametresi önemlidir. Bunlar uygun şekilde tasarlanmış terminalleri ve bu turizm yerlerine rahat ve verimli erişilebilir yolculuklar sağlayan gezi planları olan saygın toplu taşıma sistemleri, taksi, otobüs ve benzeriyle de desteklenmelidir (Alkheder, 2016).

Turizmde ulaştırma hizmeti, demiryolu, karayolu, denizyolu ve havayolu ulaşım sistemlerinden en az biri ile yapıldığ gibi kendi aralarında da iş birliği önemlidir (Doğaner, 1998). Bu yüzden turizmi ulaşım olmadan düşünmek imkansızdır. Ulaşımın gelişimi, ulaşım araçları, altyapı ve bu sektörde yeni teknolojilerin kullanılması turizmin gelişmesini hızlandırmaktadır (Mammadov, 2012). Turizm faaliyetlerine katılım insanların yaşadıkları yerden farklı bir yere gitmeleriyle 
gerçekleşmektedir. Dolayısıyla bir ulaşım türü tercih edilerek seyahat edilmektedir. Her ulaşım türünün avantaj ve dezavantajları bulunmaktadır. Ulaşım türleri aşağıda kısaca açıklanmakta ve çalışmanın temel konusu olan demiryolu ulaşımına ilişkin ayrıntılı bilgi verilmektedir.

Karayolu Ulaşımı: Kişinin veya yükün taşıyıcı tarafından belirli bir yerden alınıp istenilen yere güvenli bir şekilde götürülmesi olarak tanımlanmakta ve ana unsurlarını; insan, yük, taşıyan ve karayolu oluşturmaktadır (Yardımcıoğlu, 2013). Otoyollar malların taşınması, işe gitme ve işten çıkma, hizmetler, sosyal ve rekreasyon amaçlı ve karmaşık toplumun işleyişi için gerekli olan birçok günlük faaliyetle iç içe geçmiştir ve bu faaliyetlerin büyük bir kısmı karayollarına bağlıdır (Wright ve Dixon, 2004). Karayolu ulaşımı, pazara giriş ve faaliyet maliyetleri en az yatırımla gerçekleşmesi, her türlü arazi koşullarında ağ oluşturmaya uygun olması (Yardımcıŏglu, 2013) sebebiyle diğer ulaşım türleri arasında en yaygın olarak kullanılanıdır (Doğan, 2014).

Havayolu Ulaşımı: Havacılık sektörü, bölge kalkınmasına hız kazandırırken diğer taraftan da ulusal ve uluslararası düzeyde öneme sahip bir sektördür (Hatipoğlu, 2015). Havayolu ulaşımı, rekabetin üst düzeyde yaşandığı karmaşık bir endüstri olmakla beraber gelişmiş teknolojiye bağımlı konumdadır (Kuyucak ve Şengür, 2009). Havacılık endüstrisi, turizm ve uçak imalatı ile ilgili endüstriler üzerindeki etkileri açısından ekonomik bir güçtür. (Belobaba, Odoni ve Barnhart, 2015). Havayolu uçuş programları, yolcu talebini karşılamak, mevcut kaynakları kullanmak ve farklı işletme gereksinimlerini karşılamak için tasarlanmıştır. İki uçuş arasındaki zaman tamponu ne kadar büyük olursa, uçuş planına göre hizmet verme olasılığı o kadar yüksektir (Babic, Kalic, Pavkovic, Cangalovic ve Dozic, 2010).

Denizyolu Ulaşımı: En düşük maliyetli ve güvenli olan ulaşım türü denizyolu taşımacılığıdır (Dursun ve Erol, 2012). Dünyanın büyük bir kısmının denizlerle kaplı olması yük sahiplerini deniz taşımacılı̆̆ına yönlendirmektedir (Saban ve Güğerçin, 2009). Kişiler tatil amaçlı, konaklamalı şekilde, büyüklüğ̈̈ ve konfor şartları belli standartlarda olan gemileri kullanmakta ve uluslararası seyahatleri gerçekleştirmektedir. Kruvaziyer turizm olarak isimlendirilen bu turizm şekli de denizyolu ulaşımını daha popüler hale getirmiştir (Dilek, Kaygalak, Türksoy ve Timur, 2015).

Demiryolu Ulaşımı: Madeni bir yol üzerinde araç sistemlerinin mekanik bir güçle hareket ettirildiği, iki nokta arasında, araçlar içerisinde yolcu veya yük taşımacıllı̆̆ gerçekleştirilen faaliyet olarak tanımlanmaktadır. Araçların bir dizi halinde bir araya getirildiği ulaşım sistemine tren adı verilmektedir (Yardımcıoğlu, 2013). Sanayi Devrimi'nin en önemli dinamiklerinden biri olan demiryolu ulaşımı, 19.yüzyıl teknolojisinde sanayileşme sürecinin zorunlu bir ihtiyacı olarak ortaya çıkmıştır. Sanayi Devrimi'nin doğduğu ülke olan İngiltere'de hız, mesafe, yük ve yolcu taşımacılığındaki maliyetlerin düşürülmesi için modern anlamda gelişim 1830 yılında gerçekleşmiştir (Akbulut, 2010). Demiryolu sektörünün gelişimi buharın kullanılması, kömür ve demir madenlerinin işlenmesinden büyük oranda etkilenmiştir. İlk demiryolu hatları 1830 yıllarında birçok Avrupa kentinde işlemeye başlamıştır. Bu durumun nedeni olarak da hızlı ulaşıma sahip olması gösterilmektedir. 1835'de İngiltere'de 100 km/sa, 1890 yılında Fransa'da 144 km/sa, 1903 yılında Almanya'da 213 km/sa hıza ulaşılmıştır (Öztürk ve Arılı, 2009). Yirminci yüzyıl boyunca, gelişmekte olan ülkelerde ağların genişlemesi devam etmiş, dünyanın daha uzak bölgelerine hizmet etmek için yeni hatlar inşa edilmiştir (Carpenter, 1994).

Demiryollarının Avrupa'da işletilmeye başlamasıyla Osmanlı'ya geliş yılları arasında çok büyük fark bulunmamaktadır. Fakat Avrupa'da veya Amerika'da demiryollarının oluşturduğu etkiler Osmanlı'da farklılık göstermiştir. Bu farklılığın sebebi ise coğrafi keşiflerden başlayarak Sanayi Devrimi'ne kadar geçen süreçtir. Coğrafi keşifler, Doğu'nun savunucusu ve sözcüsü olan Osmanlı İmparatorluğu'nun dünyanın merkezindeki yerinin sarsılmasına yol açmıştır (Akbulut, 2010). Osmanlı Devleti'nin son döneminde, kaynakların kıt ve askeri sıkıntıların yoğun olduğu yıllarda, Anadolu ve Bağdat Demiryolları, Rumeli Demiryolları ve Hicaz Demiryolları son derece önemli yatırımlar olarak değerlendirilmiştir. Demiryollarına olan ilgi Osmanlı Devleti'nin çöküş dönemi ile başlamaktadır. 19. yüzyılın ikinci yarısında başlayan bu süreçte, finansal kaynakların son derece sınırlı olduğu, birçok bölgede ise krizlerin yaşandığı, demiryolu teknolojisi ve işletmeciliği alanında ise birikimin yetersiz 
olduğu gerçeği bulunmaktadır (Erdal, Güvenler ve Sandalcı, 2009). Türkiye Cumhuriyeti kurulduğunda Tablo 1'de görüldüğü gibi ülkede 4112 km'lik demiryolu bulunmaktadır. Bu demiryollarından 3756 km'si imtiyazlı yabancı şirketler tarafından inşa edilmiştir. İşgal yıllarında Doğu Anadolu'daki 356 km'lik demiryolu ise Ruslar tarafından inşa edilmiştir (Yıldırım, 2001).

Tablo $1^{*}$

1923 Yılında Türkiye'deki Demiryolları

\begin{tabular}{lcc}
\hline Hattın Adı & Genişliği $(\mathrm{m})$ & Uzunluğu $(\mathrm{Km})$ \\
Adana-Mersin Hattı & Normal (1.435) & 68 \\
İzmir-Kasaba Hattı & Normal (1.435) & 703 \\
İzmir-Aydın Hattı & Normal(1.435) & 609 \\
Şark Demiryolları Hattı & Normal(1.435) & 337 \\
Mudanya-Bursa Hattı & $\operatorname{Dar}(1.050)$ & 41 \\
Erzurum-Sarıkamış Hattı & $\operatorname{Dar}(0.750)$ & 232 \\
Sarıkamış-Sınır Hattı & Geniş (1.524) & 124 \\
Toplam & & 4112 \\
\hline
\end{tabular}

"Kaynak: Yıldırım, İ., (2001). Cumhuriyet döneminde demiryollarl (1923-1950), Atatürk Araştırma Merkezi, Ankara.

Milli Mücadelenin bitmesine yakın, 1 Mart 1922'deki meclis konuşmasında demiryolları ulaşımına değinen Mustafa Kemal Paşa “(...) Ancak inşaat ve tesisatın genişletilmesi mali durumumuzla gayri mütenasip cesim sermayelere mütevakkıf olan umur-u nafiada ecnebi sermayesinden ve icabona göre ecnebi mütehasslslardan azami derecede istifade etmek, memleketimizin menfaat ve mamuriyetini ve milletimizin saadet ve refahın az zamanda temin nokta-i nazarında zaruridir(...)" diyerek, bu konuda gerekirse yabancı sermayeye başvurabileceğini de vurgulamıştır. Cumhuriyetin kuruluşunda $4.112 \mathrm{~km}$ olduğu belirtilen demiryolu uzunluğu, yeni hatlar ile 1930 'da 5.639 'a, 1935 'te de 6.639 km'ye ulaşmıştır. Sonraki yıllarda tamamlanan demiryollarının önemli bir kısmına da bu dönemde başlanmıştır (As, 2006).

1. Beş Yıllık Sanayi Planında ve 2. Beş Yıllık Sanayileşme Planı'nda Türkiye, ulaşım sıkıntısını çözmek ve temel sanayi girdilerinin hacimli ve yoğun yüklerini demiryolları ile en ucuz biçimde taşımak amacı ile bilinçli bir demiryolu politikası izlemiştir (Türkiye Makine Mühendisleri Odası Birliği, 2012). 1923-1945 yılları arasında demiryolu fabrikaları kurulmuş, ilgili atölyeler açılmış ve nitelikli işgücünün sağlanması için okullar açılmıştır. 1923 yılında Konya ve İstanbul'daki Şimendifer Okulları ile Sivas ve Eskişehir'deki Cer Atölyeleri, planlanan politikaların hayata geçirildiğinin göstergeleri olmuştur (Akın ve Sultanoğlu, 2006).

1950 yılından itibaren karayolu gelişimine verilen önem diğer ulaşım türlerine verilmemiştir. Tablo 2'de görüleceği üzere 1970 yılı itibariyle karayolu ağırlıklı taşımacılık yapılmaya başlanmıştır. Bunun sonucunda 1951-2003 döneminde sadece $945 \mathrm{~km}$ demiryolu yapılabilmiştir. 2003 yılından itibaren ulaştırma sistemleri içerisinde demiryolu yatırımlarına önem verilmesiyle 2004-2016 döneminde 1.805 km yeni demiryolu kullanıma açılmıştır (Türkiye Cumhuriyeti Devlet Demiryolları, Demiryolu Sektör Raporu, 2017).

Tablo $2^{*}$

Taşımacıllğı̆n Ulaştırma Türlerine Göre Dağılımı Yük (Netton-km) Yolcu (Yolcu-km)

\begin{tabular}{ccccccccc} 
Y1llar & Karayolu & Demiryolu & Denizyolu & Havayolu & Karayolu & Demiryolu & Denizyolu & Havayolu \\
1950 & 25 & 68,2 & 6,8 & 0 & 50,3 & 42,2 & 7,5 & 0 \\
1960 & 45 & 52,9 & 2 & 0,1 & 72,9 & 24,3 & 2 & 0,8 \\
1970 & 75,4 & 24,3 & 0,2 & 0,1 & 91,4 & 7,6 & 0,3 & 0,7 \\
2000 & 90,1 & 5,4 & 6,4 & 0,1 & 96 & 2,2 & 0 & 1,8 \\
2010 & 89,9 & 5,3 & 5 & 0 & 97,8 & 1,6 & 0,7 & - \\
2015 & 89,8 & 3,9 & 6,3 & 0 & 89,2 & 1,1 & 0,6 & 9,1 \\
\hline
\end{tabular}

*Kaynak: TCDD İşletmesi Genel Müdürlüğü, (2017). Demiryolu Sektör Raporu 2016. 
Turizm amaçlı kitle seyahatlerinin ilk taşıma araçları olan trenler 19. yüzyıl boyunca turizm hareketlerinin gelişmesinde önemli bir paya sahip olmuştur. Ekonomik olması, güvenli olması, sosyalleşme imkânı tanıması ve çevreyle dost olması özellikleri nedeniyle trenler, diğer ulaştırma araçlarına kıyasla avantajlı konumdadır (Şahbaz ve Yüksel, 2008). Turizm alanında demiryollarının dikkat çekmesi 'özel tren kiralama' uygulaması ve belirli hatlarda 'özel tren turlarıyla', konaklama, ağırlama ve ulaşım hizmetlerini bir arada sunan 'Tren Turizmi'nin başlamasıyla olmuştur (Doğaner, 1996). Alışılmış trenlerin dışında, farklı birkaç özelliği bulunan trenlerle ya da ilgi çekici güzergahlardaki tren yolcuklarını tercih eden turistlerin oluşturdukları turizm hareketi 'demiryolu turizmi’ olarak tanımlanmaktadır (Çakıcı, 2019). Bu bağlamda Doğu Ekspresi, demiryolu turizminin canlanmasında önem arz eden alternatif bir güzergâh olarak nitelendirilmekte ve ekspresin son durağ1 olan Kars iline ilgi artmaktadır.

Kars adının geçmişi Karsaklardan gelmektedir. M.Ö. 130-127 yıllarında Kafkas dağlarının kuzeyinden ve Dağıstan'dan gelerek Kars çevresine yerleşmiş ve buraya adlarını vermişlerdir. Bu durumdan dolayı Türkiye'deki en eski Türkçe İl adı ününün sahibi olmuştur (Kars İl Kültür ve Turizm Müdürlüğü Web Sitesi, 2019). Kars ili semt olarak eski ve yeni olmak üzere ikiye ayrılmaktadır. Eski Kars, kuzeyde bir tepe üzerindeki Kars Kalesi çevresinde bulunmaktadır. 1878'den sonra kurulan Yeni Kars, ovaya doğru yayılmıştır. 1828, 1855 ve 1877 'de üç kez Ruslar tarafindan işgal edilmiş ve en sonuncu işgal de yaklaşık 40 yıl Rus egemenliğinde kalmıştır (Atalay ve Mortan, 1995).

Kars İli, bulunduğu konum itibariyle jeopolitik bir öneme sahiptir. Bu önemi pekiştiren durum ise, Kafkaslarla Anadolu'yu birbirine bağlayan önemli bir nokta olmasıdır. Ayrıca il, Kafkas coğrafyasının da bir parçasıdır (Bingöl, 2011). Günümüze kadar birçok kültür ve medeniyetin etkisi altında kalan şehir, sahip olduğu tarihi eserler ve kültürel miraslarından dolayı Kültür ve Turizm Bakanlığı tarafından koruma altına alınarak tarihi sit alanı olarak ilan edilmiştir (Demir, 2017).

En yoğun ilgiyi kent yakınlarında bulunan Ani Kenti Ören Yeri, Kars'ta bulunan tarihi eserler ve Sarıkamış'ta bulunan kayak merkezi çekmektedir (Demir ve Alım, 2017). Ani Şehri Kars ilinin 44 kilometre doğusunda Ocaklı köyü yanında bulunmaktadır. Aras Nehri'nin Arpaçay kolu kıyısındaki Ani'nin kuzeydoğusunda Tatarcık, batısında ise Bostanlar deresi akmaktadır. Harabelerin bulunduğu yer, Türkiye ile Ermenistan'ı birbirinde ayırmaktadır. Her mevsim turist çeken kentte, turistlerin çoğu; yaz aylarında Doğu Anadolu ve Karadeniz'e yapılan kültür turları kapsamında kenti ziyaret ederek diğer illere hareket etmektedir (Yiğitbaş, 2014).

Haziran-Ekim ayları arasındaki yaz döneminde gelen turistler genel olarak kenti, Ani Antik Kentini ve Sarıkamış civarındaki ormanlık alanları ziyaret etmektedirler. Aralık-Nisan ayları arasında kalan kış döneminde ise soğuk hava koşulları sebebi ile turistlerin büyük bir çoğunluğu Sarıkamış Bayraktepe Kış Turizm Merkezini ziyaret etmektedir (Demir, 2017). Kars il merkezi, ulaşım bakımından elverişli bir konuma sahip olup, havaalanına $50 \mathrm{~km}$ uzaklıkta bulunmaktadır (Demir ve Alım, 2016).

Doğu Ekspresi Ankara'dan yola çıkarak Kırıkkale, Kayseri, Sivas, Erzincan, Erzurum ve Kars ana hattında (Harita 1) sefer yapan ve yaklaşık 1300 kilometrelik yolu 25 saatte tamamlayan, Türkiye Cumhuriyeti Devlet Demiryolları (TCDD)'na ait bir eksprestir. Tarihi açıdan bakıldığında ekspresin Ankara'dan başlayarak Kars'a uzanması 1961 yılında gerçekleşmiş̧ir (Çakmak ve Altaş, 2018). 


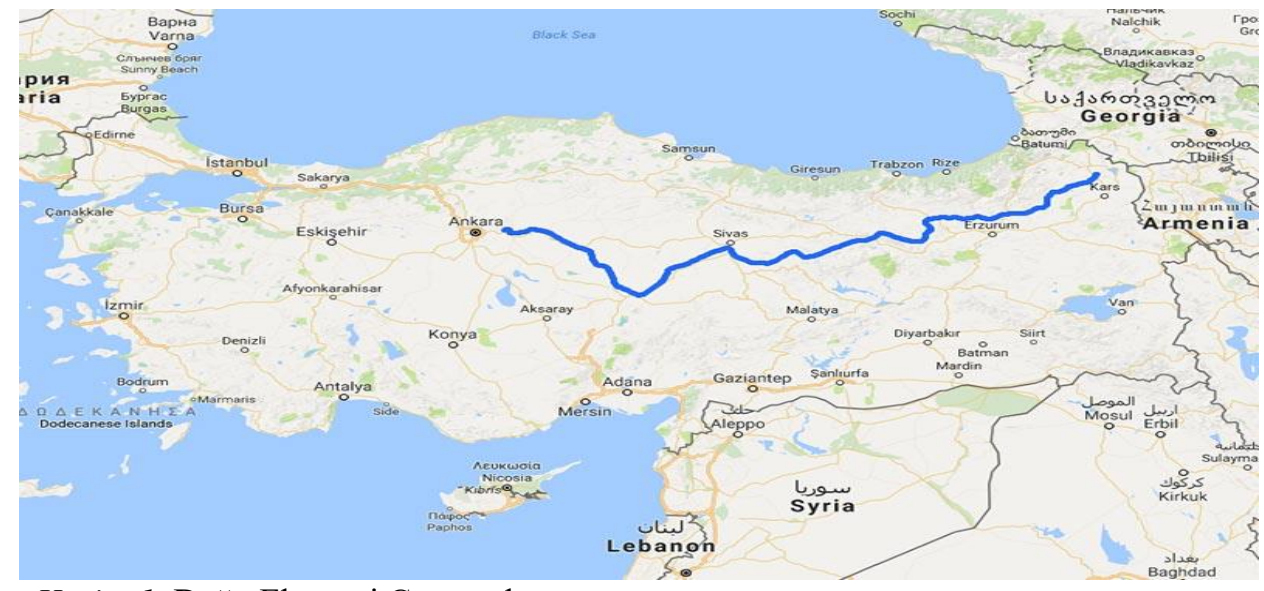

Harita 1: Doğu Ekspresi Güzergahı

(Kaynak: INT I. https://www.rotasenin.com/dogu-ekspresi)

Doğu Ekspresi hattının Ankara-Kars güzergahı kademeli biçimde tamamlanmıştır. 1927'de Ankara-Kayseri hattının inşasının bitmesi ile demiryolu Kayseri'ye ulaşmıştır. 1930 yılında Şarkışla istasyonunun açılmasıyla birlikte Ankara-Sivas arasında demiryolu ulaşımı sağlanmıştır. Demiryolu hattı 7 Ekim 1938 tarihinde Erzincan'a, 6 Eylül 1939'da ise Erzurum'a ulaşmıştır. Demiryolunun Erzurum'a ulaşmasıyla hat, Rusların inşa etmiş olduğu Erzurum-Kars demiryolu hattına bağlanmıştır. Sivas-Erzurum hattının tamamlanıp demiryolunun Kars'a ulaşmasıyla Doğu Ekspresi'nin güzergahı olan hat meydana gelmiştir (Ceylan, Ceylan ve Yaman, 2018).

Doğu Ekspresi dört yatakl1, dört pulman, iki kuşetli ve bir yemekli vagon seçenekleri ile seferlerini gerçekleştirmektedir. Bulunan vagonların tamamı bireysel yolculara tahsis edilerek 30 gün öncesinden satışına başlanmaktadır. Ankara-Kars arasında 52 istasyonda durarak yolcu alıp yoluna devam etmektedir. Son zamanlarda artan talebe karşılık trene ilave vagonlar tahsis edilmiştir (TCDD, Demiryolu Sektör Raporu, 2017). Doğu Ekspresi treninde kompartımanlı, pulman, örtülü kuşet, yemek ve yataklı vagon bulunmaktadır. Pulman vagonların 180 , örtülü kuşetli vagonun 80 , yataklı vagonların 100 kişilik yolcu kapasitesi bulunmakta ve Doğu Ekspresi tek seferde 360 yolcuya hizmet vermektedir (Ceylan vd., 2018).

Pulman, tüm seyahat boyunca koltukta yolculuk sağlayan ve her vagonda bir adet lavabosu bulunan bir vagon türüdür. Örtülü kuşetli vagon türü ise dört kişinin konaklayabilecekleri karşılıklı açılır kapanır iki ranzaya sahip olan vagon türüdür. Doğu Ekspresi’nin en çok tercih edilen türünün de yataklı vagon olduğu tespit edilmiştir. Tercih edilme sebepleri ise, iki kişilik olarak tasarlanıp oda içerisinde mini buzdolabı, odaya ait lavabo ve rafların bulunması gösterilmektedir (Tuna, 2018). Seyehat acentalarının hazırladığı paket turlarda, turistlerin uzun süren yolculuk süresince rahat etme isteğini karşılamak üzere, özellikle yataklı vagonların yer aldığı dikkat çekmektedir. Turistik amaçlı seyahat etmeyen ve ekonomik olarak karşılama gücü olanlar için de amaç aynı olunca bu vagonlara talep fazla olmaktadır.

Kars ili, kış koşulları ve mevsimsel özellikleri nedeniyle Ocak, Şubat ve Mart aylarını kapsayan dönemi, turistik çekiciliği ön plana çıkarmaktadır. Popüler kültürün gerisinde kalmak istemeyen ve sosyal medyayı aktif biçimde kullanan insanların bu deneyimi yaşamak istedikleri görülmektedir (Doğan, Pekiner ve Karaca, 2018). Turizm işletmeleri ise bu doğrultuda sosyal medya platformlarını ve çoğunlukla instagramı tanıtım ve pazarlama amaçlı olarak kullanmaktadır (Bayrak, Doğan ve Ergun, 2019). Instagramın Doğu Ekspresi üzerindeki yarattığı pazarlama etkisini gözlemlemek mümkündür. Instagramdaki Doğu Ekspresi ile ilgili paylaşımlar ve beğeni sayıları dikkat çekici boyutlara ulaşmıştır. Instagramın yanı sıra dünyanın en büyük video paylaşım platformu olan Youtube'da Doğu Ekspresine özel videolar paylaşılmaktadır (Eryılmaz ve Yücetürk, 2018). Bu paylaşımlarda dikkat çeken tema 25 saatlik yolculuğa ilişkin tüyolardır. Farklı bakış açılarıyla ekspreste yapılan seyahate ilişkin izlenimlerin yer aldığı videolar bulunmaktadır. 
Son zamanlarda ünlü gezginlerin Kars'a olan gezileri dikkat çekmektedir. Pazarlama çemberini büyütmek ve ses uyandırmak için instagramda takipçi sayısı milyonları geçen kişilere sponsor olunup reklamlar yaptırlmakta ve bu sayede Doğu Ekspresi'ne olan ilgi günden güne katlanarak artmaktadır. Özellikle 18-25 yaş arası gençler tarafından tercih edildiği bilinmektedir. 2016 yılına göre \%40'lık bir artış gözlemlenmesi ile birlikte bir olan yataklı vagon sayısı Kars'a yapılan bazı seferlerde üçe çıkarılmıştır. Artan ilginin sonucunda otellerde de \%100 doluluk yaşandığ1 kaydedilmiştir (Hamzaçebi ve Yozgat, 2019). Araştırmalar, geçmiş zamanlar da olduğu gibi günümüzde de demiryollarının tercih edilmesinde 'ucuzluk' ve 'güvenlik' unsurlarının büyük rol oynadığını göstermektedir (Kozak, Kozak ve Kozak, 2006).

Doğu Ekspresi'nin tercih edilme nedenlerinden bir diğeri ise diğer ulaşım araçlarına oranla daha ucuz olmasıdır. Ankara ilinden Kars'a gitmek isteyen bir kişi ulaşım aracı olarak Doğu Ekspresi pulman seçiminde koltuk ücreti havayollarına göre \%135 daha uygundur ve karayollarına oranla da \%73 daha ucuz olduğu belirlenmiş̧ir. Doğu Ekspresi'nin diğer kategorilerine göre oranlar ise şöyledir: Örtülü kuşetli vagon ücreti havayollarına oranla \%119, karayollarına oranla ise \%57 daha uygundur. Ekspresin en konforlu ve kategorik fiyatlandırmaya göre pahalı olan seçeneği yataklı vagon ise havayollarına oranla \%65, karayollarına göre ise \%3 daha uygundur. Çalışmada, Doğu Ekspresi ile seyahat eden yolculara ilişkin durum analizi yaparak, Doğu Ekspresi'nin Kars'taki turizm faaliyetlerine etkisinin belirlenmesi amaçlanmıştır. Çalışma kapsamında aşağıdaki araştırma sorularına yanit aranmaktadır:

- Doğu Ekspresi hangi tarihten sonra duyulmuştur?

- Doğu Ekspresi yolcularının seyahat neden/nedenleri nelerdir?

- Doğu Ekspresi yolcularının Kars’ta ortalama kalış süresi ne kadardır?

- Doğu Ekspresi Kars’taki konaklama işletmelerinin doluluk oranını etkilemiş midir?

- Doğu Ekspresi’nin destinasyon ve işletmeler üzerindeki etkileri nelerdir?

\section{Yöntem}

Sosyal medya turizm faaliyetlerine katılımı arttırmakta, yani ulaşım ve konaklama işletmelerinde hareketliliğe sebep olmaktadır. Bu durum araştırma deseninin şekillenmesine esas oluşturmuştur. Sosyal medyadaki Doğu Ekspresi paylaşımları, ekspres yolculukları ve Kars'taki konaklama işletmeleri araştırmanın temel bileşenlerini oluşturmaktadır. Bu bağlamda iki aşamalı bir araştırma gerçekleştirilmiş olup çalışmada nicel ve nitel araştırma teknikleri birlikte kullanılmıştır. Anket soruları oluşturulurken Eryılmaz ve Yücetürk (2018), Doğan ve diğerleri (2018), Ceylan ve diğerlerine (2018) ait çalışmaların anket soruları dikkate alınmıştır. Doğu Ekspresi yolcularına anket uygulanmıştır. Ayrıca Kars'ta faaliyet gösteren konaklama işletmelerinin yetkilileriyle yarı yapılandırılmış mülakat gerçekleştirilmiştir.

\section{Evren ve Örneklem}

Araştırmanın evreni Doğu Ekspresi yolcuları ve Kars'ta hizmet veren konaklama işletmeleridir. Çalışma genel hatlarıyla iki ayrı örneklemi temsil etmektedir. İlk örneklem Doğu Ekspresi'nde Kars-Ankara güzergahında seyahat eden yolculardan oluşmaktadır ve kolayda örnekleme yöntemi kullanılarak anketi doldurmayı kabul eden yolculardan toplanan anketler değerlendirmeye alınmıştır. Kars'ta konaklayarak dönüş yolunda olan yolcular tercih edilmiş olup, yolculuk esnasında anket uygulaması gerçekleştirilmiştir. Maddi ve zamansal yetersizlik nedeniyle Doğu Ekspresi'nin bir seferinde çalışmanın yürütülmesi araştırmanın kısıtları arasında değerlendirilmektedir. Çalışmanın ikinci kısmını oluşturan örneklem ise Kars ili şehir merkezinde bulunan konaklama işletmelerinin yöneticileridir. 


\section{Veri Toplama Araçları}

Anket soruları 28 Şubat 2019 saat 08:00'de Kars'tan yola çıarak Ankara istikametinde seyahat eden Doğu Ekspresi yolcularına uygulanmıştır. Doğu Ekspresi yolcularına seyahat sırasında uygulanmak üzere ekspresi tercih etme durumları ve duyumlarına ilişkin 6'sı katılımcıların demografik özelliklerini içeren toplam 20 adet sorunun yer aldığ 1 anket uygulanmıştır. Bu soruların 19 tanesi kategorik biçimde ve geriye kalan 1 soru ise açık uçlu olarak hazırlanmıştır ve sorularda uzman görüşleri alınmıştır. Anket toplam 60 kişi tarafindan cevaplandırılmış olup, 7 adet form eksik/tutarsız cevaplandırılması sebebiyle değerlendirme dışında tutulmuştur. Zamansal-maddi kısıtlar ve Doğu Ekspresi'nde bilet bulma kisitı nedenleriyle Kars'tan Ankara'ya tek seferde seyahat eden yolcular üzerinde bir araştırma gerçekleştirilmiş olması araştırmanın sınırlılıkları arasında yer almaktadır. Nitel araştırma yöntemlerinden yarı yapılandırılmış görüşme Kars'ta faaliyet gösteren 15 konaklama işletmesinin yetkilileriyle yüz yüze gerçekleştirilmiştir. İşletme yöneticileriyle gerçekleştirilen yarı yapılandırılmış mülakatlarda; Kars'taki konaklama işletmelerine ilişkin genel değerlendirmeye ve Doğu Ekspresi'nin Kars’taki turizm faaliyetlerine etkisine ilişkin sorular yönlendirilmiştir.

\section{Verilerin Analizi}

Doğu Ekspresi'nde seyahatleri sırasında katılımcılara sunulan açık ve kapalı uçlu sorulardan oluşan anket yardımıyla elde edilen veriler SPSS veri analiz programına girilerek frekans analizine tabi tutulmuştur. Ayrıca katılımcıların demografik özelliklerine göre değikenlerin farklılık arz edip etmediği incelenmiştir. Konaklama işletmelerinde gerçekleştirlen görüşmeler ses kaydına alınmış ve katılımcılar tarafindan verilen cevaplar deşifre edilerek yoğunlaşılan temalar ortaya çıkarılmıştır. Veriler bu ana temalar üzerinden değerlendirilerek aktarılmıştır.

\section{Bulgular}

\section{Doğu Ekspresi’ne İlişkin Bulgular}

Doğu Ekspresi'nde seyahat eden 53 katılımcının verdiği yanıtlar analize tabi tutulmuştur. Katılımcıların yaş, cinsiyet, eğitim ve gelir durumunu gösteren demografik özelliklerine ilişkin veriler Tablo 3'te yer almaktadır. Katılımcıların \%85'i kadın, \%51'i ise 55 yaş ve üzeridir. Eğitim seviyesi açısından değerlendirildiğinde ise katılımcıların \%67'sinin lisans mezunu olduğu görülmektedir. Gelir durumu açısından bakıldığında veriler normal dağılım göstermektedir.

Tablo 3

Katılımciların Demografik Özellikleri

\begin{tabular}{llc}
\hline Demografik Özellik & Kategori & $\%$ \\
Cinsiyet & Kadın & 85 \\
Yaş & Erkek & 15 \\
& $18-24$ & 2 \\
& $25-34$ & 30 \\
& $35-44$ & 6 \\
& $45-54$ & 11 \\
Medeni Durum & 55 ve üzeri & 51 \\
& Bekar & 55 \\
Eğitim Seviyesi & Evli & 45 \\
& İköğretim & 2 \\
& Lise & 19 \\
& Ön lisans & 6 \\
Aylık Gelir & Lisans & 67 \\
& Lisansüstü & 6 \\
& 1500 TL ve altı & 9 \\
& $1501-2500$ & 21 \\
& $2501-3500$ & 21 \\
& $3501-4500$ & 23 \\
\hline
\end{tabular}


Katılımcıların Doğu Ekspresi'ne katılım şekilleri çoğunlukla (\%41) tur şirketleri tarafindan gerçekleştirilmiştir (Tablo 4). Tur şirketlerinin Doğu Ekspresi biletlerini toplu bir şekilde satın almasından dolayı insanlar bilet bulma sıkıntısı çekmemek adına tur şirketlerini tercih ettiklerini belirtmiştir.

Tablo 4

Katılımcıların Doğu Ekspresi’ne Katılım Şekilleri

\begin{tabular}{ll}
\hline Katılım Şekli & $\%$ \\
Bireysel & 38 \\
Grup & 21 \\
Tur Şirketi & 41 \\
\hline
\end{tabular}

Katılımcıların \%45'i yılda 3-6 defa seyahate çıktıklarını belirtirken, 2 kez ve altında seyahate çıkanların oranı \%36'dır. Katılımcıların seyahat amaçları incelendiğinde çoğunluğun (\%91) turistik amaçlı seyahat ettikleri tespit edilmiştir. Eğitim amaçlı seyahat eden katılımcılar (\%4) Kafkas Üniversitesi'nde okuduklarını ve ailelerini ziyarete gitmek amacıyla seyahat ettiklerini belirtmişlerdir. Geri kalan \%5'lik kısım ise aile ziyareti ve iş amaçlı seyahat etmektedir. Katılımcıların Doğu Ekspresi duyumlarına ilişkin bilgiler Tablo 5'te verilmiştir. Katılımcıların \%62'sinin Doğu Ekspresi'ni 20162019 yılları arasında sosyal medyadan (\%51) duydukları tespit edilmiştir. Son yıllardaki instagram, facebook ve diğer sosyal medya araçlarında yapılan Doğu Ekspresi paylaşımları insanları bu seyahat şekline yönlendirmede büyük bir etki yaratmıştır. Doğu Ekspresi'nin popülaritesinde ağızdan ağıza iletişimin ve televizyonun öneminin de fazla olduğu görülmektedir.

Tablo 5

Katılımcıların Doğu Ekspresi Duyumlarına İlişkin Bilgiler

\begin{tabular}{llc}
\hline \multirow{2}{*}{ İk kez duyulduğu ortam } & & $\%$ \\
& Televizyon & 17 \\
& Seyahat Acentesi & 2 \\
& Yakın Çevre & 26 \\
İlk duyulduğu zaman aralığı & Sosyal Medya & 51 \\
& Gazete & 2 \\
& Diğer & 2 \\
& 2005 ve öncesi & 4 \\
& $2006-2010$ & 8 \\
\hline
\end{tabular}

Hızlıca gelişen teknolojinin etkisiyle hızla yaygınlık gösteren sosyal medya platformları, insanların aradıkları bilgilere ulaşma konusunda büyük kolaylıklar sağlamaktadır. Doğu Ekspresi'nin de son zamanlarda sosyal medya ve benzeri iletişim araçları sayesinde hızla tanınırlığının arttığı görülmektedir. Katılımcılara 'Doğu Ekspresi ile ilgili güvenilir bilgileri nereden aldınız?' sorusu yönlendirilmiş ve çıkan sonuçlarda sosyal medya (\%47) ve yakın çevre $(\% 30)$ güvenilir bilgi kaynağ olarak nitelendirilmiştir.

'Kars'a varışınızı hangi ulaşım aracı ile gerçekleştirdiniz?' sorusuna katılımcıların \%55'i uçak cevabını vermiştir. Bunun sebebinin; satın alınan turları düzenleyen seyahat acentalarının Kars'a uçak ile yolcu göndermeleri ve geri dönüşlerini tren ile sağlamaları olduğu tespit edilmiştir. Kars'a otobüsle giderek Doğu Ekspresi ile dönenlerin oranı ise $\% 25$ 'tir. Gidiş-dönüş iki güzergahta da tren kullananlar ise sadece \%17'lik dilimi oluşturmaktadır. Katılımcılara Doğu Ekspresi ile yapılan seyahat sıklı̆g 1 ile ilgili yönlendirilen soruda büyük çoğunluğun (\%81) ilk defa seyahat ettiği belirlenmiştir. Anket uygulaması sırasında katılımcılarla yapılan görüşmelerde eksprese bir daha binmek istediklerini beyan etmişlerdir. Katılımcıların \%13'ü ise Doğu Ekspresi'ndeki ikinci seyahatleri olduğunu aktarmıştır. 
Katılımcılara 'Doğu Ekspresi ücretlendirmesini nasıl buluyorsunuz?' sorusu yönlendirildiğinde çoğunluk tur şirketlerinin hazırlamış olduğu tur kapsamında seyahat etmeleri sebebiyle fiyatlar konusunda fazla bilgiye sahip olmadığını belirtmiştir. Fiyat konusunda bilgilendirme yapıldıktan sonra soru katılımcılar tarafından yanıtlanmıştır. Büyük bir kesim (\%70) Doğu Ekspresi bilet ücretlerini orta seviye de bulurken gelir durumu yüksek olan katıllmcilar ise biletleri ucuz bulmuştur. Doğu Ekspresi tarifelerini pahalı bulan katılımcılar ise sadece \%4'lük dilimi oluşturmaktadır.

Katılımcıların Kars'ta bulundukları süre ise çoğunlukla 1-3 gün arasındadır (Tablo 6: \%66). Katılım şeklinin büyük oranda tur şirketi aracılığıyla gerçekleştirmesinin ziyaret süresi ile doğru bir orantısı olduğu görülmektedir. Doğu Ekspresi ile tur düzenleyen şirketler çoğunlukla seyahat süresini 3 günlük turlar şeklinde hazırlamaktadır. Katılım şekli ve ziyaret süreleri birbirini destekler niteliktedir.

Tablo 6

Katılımcıların Kars'ta Kalış Süresine Illişkin Bilgiler

\begin{tabular}{llc}
\hline & & $\%$ \\
Kars'ta Kalış Süresi & $1-3$ gün & 66 \\
& 4-6 gün & 26 \\
& $6-8$ gün & 2 \\
& 9 gün ve üstü & 6 \\
\hline
\end{tabular}

Kars'ta kaldıkları süre zarfında konaklama yeri tercihleri incelenmiş ve katılımcıların \%72'sinin otelde kaldıkları belirlenmiştir. Katılımcıların \%18'i ise akrabalarında kalmayı tercih etmektedir. Konaklama işletmelerinin fiyatlarını nasıl buldukları sorusunda katılımcıların büyük bir çoğunluğu tur şirketlerini tercih ederek paket halinde satın alma gerçekleştirmeleri sebebiyle tur fiyatlarını temel almıştır. Katılımcıların \%64'ü Kars'taki konaklama fiyatlarını orta düzeyde bulduğunu aktarırken, \%23’ü ise fiyatların pahalı olduğunu belirtmektedir.

\section{Konaklama İşletmelerine İlişkin Bulgular}

Kars'ta faaliyet gösteren 2'si zincir, 13'ü bağımsız toplam 15 konaklama işletmesiyle görüşme yapılmıştır. İşletmelerin \%60’ı Bakanlık belgeli, 4-5 yıldıza sahiptir. Görüşülen işletmelerin \%33’ü 20 'den az odaya sahiptir. Şehir merkezinde bulunan otellerin daha küçük ve daha az yatak kapasitesine sahip oldukları ve şehir merkezinden uzaklaştıkça birkaç büyük otelin bulunduğu gözlemlenmiştir. Görüşme sağlanan işletmelerin büyük bir kısmının $(\mathrm{N}=13)$ tutundurma aracı olarak sosyal medya kanallarını kullandıkları tespit edilmiştir. Son yıllarda büyük bir etkiye sahip olan sosyal medya, işletmelerin de bir numaralı tutundurma aracı haline gelmiştir.

Görüşme yapılan konaklama işletmelerinin yarıdan fazlası (8) 5 yıl ve daha az süredir (Tablo 7) hizmet vermektedir. Y1l aralıklarına bakıldığında işletmelerin Doğu Ekspresi'nin ilgi odağı olduğu dönemde hizmet vermeye başlamış olduğu dikkat çekmektedir. Görüşme yapılan işletmelerin tamamı tüm y1l hizmet vermekte olup, k1ş döneminin \%100 doluluk oranıyla en yoğun dönem olduğu belirtilmiştir. Katılımcılar, misafirlerin yaş ortalamaları sorulduğunda ise genel anlamda orta yaşa sahip kişileri ağırladıklarını ve bu misafirlerin yeni yerler gezip görmeye büyük ilgileri olduğunu aktarmıştır.

Tablo 7

Konaklama Issletmelerinin Hizmet Süresi

\begin{tabular}{llll}
\hline & N & $\%$ \\
Hizmet Süresi & Yildan az & 2 & 13.3 \\
& 1-5 Yil & 6 & 40 \\
& 6-10 Yil & 3 & 20 \\
& 11 Yil ve üzeri & 4 & 26.7 \\
\hline
\end{tabular}


Kars ilinde bulunan konaklama işletmeleri çoğunlukla oda-kahvaltı (B\&B) şeklinde hizmet vermektedir. Bu duruma gerekçe olarak ise Kars'a gelen turistlerin diğer öğünlerini geleneksel restoranlarda yeme isteklerinden kaynaklandığ 1 öne sürülmektedir. Diğer bir neden olarak gelen turistlerin çoğunlukla tur şirketleri ile geldikleri ve kahvaltı dişındaki öğünlerini gezi yerlerinde bulunan anlaşmalı restoranlarda karşılandıkları belirtilmiştir. Fakat yukarıda belirtilen gerekçeler dışında meydana gelen konaklamalar için bazı oteller (\%40) brunch, öğle yemeği ve akşam yemeği hizmetlerini de ek olarak sunmaktadır. Sadece 1 işletmede 'herşey dahil' sistem uygulandığ belirtilmiştir.

Çalışma kapsamına alınan işletmeler için 'katılımcı' kavramının kısaltması olarak ' $\mathrm{K}$ ' harfi kullanılmış ve her bir katılımcı-işletmeye kod atanmıştır. Görüşme yapılan katılımcılara ait demografik özellikler ve deneyim süreleri Tablo 8'de verilmiştir. Görüşme yapılan yöneticilerin \%70'i 21-40 yaş aralı̆̆ında, \%86'sı üniversite mezunudur. Genç ve eğitimli yöneticilerin sektörde bu pozisyon altında yerini alması önemli bir gelişmedir. Bununla birlikte Kars'ta faaliyet gösteren ve görüşme yapılan konaklama işletmelerinin sadece 1 tanesinde kadın yönetici olması ilgi çekicidir. K7 kodlu katılımcı ise eğitim seviyesi, deneyim ve işletmedeki çalışma süresi sorularını yanıtsız bırakmıştır.

Tablo 8

Katılımcıların Demografik Özellikleri (Konaklama İşletmeleri)

\begin{tabular}{|c|c|c|c|c|c|c|}
\hline İşletme & Cinsiyet & Yaş & $\begin{array}{l}\text { Medeni } \\
\text { Hal }\end{array}$ & Eğitim Seviyesi & $\begin{array}{l}\text { Toplam Deneyim } \\
\text { Süresi }\end{array}$ & $\begin{array}{l}\text { Bulunduğu } \\
\text { İşletmede } \\
\text { Çalıșma Süresi }\end{array}$ \\
\hline $\mathrm{K} 1$ & Erkek & $21-30$ & Bekar & Lisansüstü & $1-5 Y_{1}$ & $1-5 Y_{1}$ \\
\hline $\mathrm{K} 2$ & Erkek & $21-30$ & Bekar & Lisansüstü & 6-10 Y1l & $1-5 Y_{1}$ \\
\hline K3 & Erkek & $41-50$ & Evli & Lisans & $1-5 Y_{1}$ & $1-5 Y_{1}$ \\
\hline $\mathrm{K} 4$ & Erkek & $21-30$ & Evli & Önlisans & 6-10 Y1l & 1 Yildan az \\
\hline K5 & Erkek & $21-30$ & Bekar & Lisans & 1-5 Y1l & $1-5 Y_{1}$ \\
\hline K6 & Erkek & $21-30$ & Bekar & Lisans & $1-5 \mathrm{Y} 1 \mathrm{l}$ & 1-5 Y1l \\
\hline K7 & Erkek & - & Evli & - & - & - \\
\hline K8 & Erkek & $31-40$ & Evli & Lisans & 11 Yil ve üzeri & 11 Yıl ve üzeri \\
\hline K9 & Erkek & $31-40$ & Evli & Önlisans & 11 Y1l ve üzeri & 11 Yil ve üzeri \\
\hline K10 & Erkek & $21-30$ & Bekar & Lise & $6-10$ Yil & $6-10$ Yil \\
\hline K11 & Erkek & $31-40$ & Evli & Lisans & $1-5 Y_{1}$ & $1-5 Y_{1} 1$ \\
\hline K12 & Erkek & $41-50$ & Evli & Lisans & 11 Yil ve üzeri & 6-10 Y 11 \\
\hline K13 & Kadın & $31-40$ & Evli & Lisans & 11 Yil ve üzeri & $1-5 Y_{1}$ \\
\hline K14 & Erkek & $31-40$ & Evli & Lisans & 11 Yil ve üzeri & $1-5 Y_{1}$ \\
\hline K15 & Erkek & $41-50$ & Evli & Lisans & 11 Yil ve üzeri & $1-5 Y_{1}$ \\
\hline
\end{tabular}

Konaklama işletmelerinde görüşülen yöneticilere yöneltilen sorular ve Doğu Ekspresi'ne iliş̧in görüşleri toplu olarak Tablo 9'da verilmiştir. İşletmelere yönlendirilen 'Doğu Ekspresi popülarite artışının işletmenize olan katkları nelerdir?' sorusuna katılımcıların \%93'ü işletmelerin doluluk oranlarının yükseldiği, buna bağlı olarak şehirde istihdamın arttığı ve il ekonomisine katkı sağladığı şeklinde yanıt vermiştir. Sadece K6 kodlu katılımcı misafirlerinin Doğu Ekspresi’ni tercih etmediğini belirtmiştir.

Doğu Ekspresi'nin popüler olmasıyla birlikte işletmelerin \%73'ü tadilata girerek yenileme çalışmaları yaptığını aktarmıştır. Ayrıca hizmet kalitesinde artış yaşandığından bahsedilmiştir. K11 kodlu katılımcı serpme kahvaltının açık büfeye çevrilip zenginleştirildiği yanıtını vermiştir. Bazı işeltmeler (K3, K7, K8) ise henüz tadilata giremediklerini fakat en yakın zamanda gireceklerini belirtmiştir. 
Tablo 9

Katılımcıların Doğu Ekspresi’ne İlişkin Görüşleri

\begin{tabular}{|c|c|c|c|}
\hline Soru & Tema & $\mathrm{N}$ & İşletme \\
\hline \multirow{2}{*}{$\begin{array}{l}\text { Doğu Ekspresi popülarite } \\
\text { artışının işletmenize olan } \\
\text { katkıları nelerdir? }\end{array}$} & $\begin{array}{l}\text { İşletmelerdeki doluluk oranının artması, } \\
\text { istihdam ve ekonomiye etkisi }\end{array}$ & 14 & $\begin{array}{l}\text { K1, K2, K3, K4, K5, K7, K8, } \\
\text { K9, K10, K11, K12, K13, } \\
\text { K14, K15 }\end{array}$ \\
\hline & $---\cdot$ & 1 & K6 \\
\hline \multirow{4}{*}{$\begin{array}{l}\text { Doğu Ekspresi popüler } \\
\text { olduktan sonraki süreçte, } \\
\text { işletmenizde gerçekleşen } \\
\text { yenilikler nelerdir? }\end{array}$} & $\begin{array}{l}\text { İşletmelere iç ve dış tadilat yapılarak } \\
\text { modern bir görünüme kavuşturulması }\end{array}$ & 11 & $\begin{array}{l}\mathrm{K} 1, \mathrm{~K} 2, \mathrm{~K} 4, \mathrm{~K} 5, \mathrm{~K} 6, \mathrm{~K} 9, \mathrm{~K} 10 \text {, } \\
\mathrm{K} 12, \mathrm{~K} 13, \mathrm{~K} 14, \mathrm{~K} 15\end{array}$ \\
\hline & ---- & 3 & $\mathrm{~K} 3, \mathrm{~K} 7, \mathrm{~K} 8$ \\
\hline & $\begin{array}{l}\text { İşletmenin serpme kahvaltıdan açık büfe } \\
\text { kahvaltıya geçmesi }\end{array}$ & 1 & K11 \\
\hline & Tur ile gelen misafir oranında artış & 6 & K8, K9, K10, K13, K14, K15 \\
\hline \multirow{4}{*}{$\begin{array}{l}\text { Doğu Ekspresi popüler } \\
\text { olduktan sonraki süreçte, } \\
\text { misafir profilinizdeki } \\
\text { değişiklikler nelerdir? }\end{array}$} & Misafirlerin yaş skalasının düşmesi & 2 & $\mathrm{~K} 2, \mathrm{~K} 7$ \\
\hline & Ülke genelinden birçok misafir gelmesi & 5 & $\mathrm{~K} 1, \mathrm{~K} 4, \mathrm{~K} 5, \mathrm{~K} 11, \mathrm{~K} 12$ \\
\hline & Misafir profilinde değişiklik olmaması & 1 & K6 \\
\hline & $\begin{array}{l}\text { Yüksek standartlara sahip misafir } \\
\text { profilinin artması }\end{array}$ & 1 & K3 \\
\hline \multirow{3}{*}{$\begin{array}{l}\text { Kars'a artan ilginin yöre } \\
\text { halkı üzerindeki yöresel } \\
\text { ve ekonomik etkileri } \\
\text { nelerdir? }\end{array}$} & Turistik ürünlerde artış yaşanması & 2 & $\mathrm{~K} 2, \mathrm{~K} 12$ \\
\hline & $\begin{array}{l}\text { Yöre genelinde ekonomik artışın } \\
\text { yaşanması }\end{array}$ & 12 & $\begin{array}{l}\mathrm{K} 1, \mathrm{~K} 4, \mathrm{~K} 5, \mathrm{~K} 6, \mathrm{~K} 7, \mathrm{~K} 8, \mathrm{~K} 9 \\
\mathrm{~K} 10, \mathrm{~K} 11, \mathrm{~K} 13, \mathrm{~K} 14, \mathrm{~K} 15\end{array}$ \\
\hline & Üretim standartlarının artması & 1 & K3 \\
\hline \multirow{5}{*}{$\begin{array}{l}\text { Kars'a artan ilginin } \\
\text { olumsuz sonuçları } \\
\text { nelerdir? }\end{array}$} & Olumsuz etkisinin olmaması & 7 & $\begin{array}{l}\text { K9, K10, K11, K12, K13, } \\
\text { K14, K15 }\end{array}$ \\
\hline & Tren seferlerinde aksamalar yaşanması & 1 & K8 \\
\hline & Altyapı ve tesislerin yetersiz kalması & 2 & K6, K7 \\
\hline & $\begin{array}{l}\text { Yöreye artan ilginin işletmeciler tarafından } \\
\text { firsatç1lığa çevrilmesi }\end{array}$ & 4 & $\mathrm{~K} 1, \mathrm{~K} 2, \mathrm{~K} 4, \mathrm{~K} 5$ \\
\hline & $\begin{array}{l}\text { Doygunluktan dolayı turistlere olan } \\
\text { saygının azalması }\end{array}$ & 1 & K3 \\
\hline \multirow{6}{*}{$\begin{array}{l}\text { Misafirlerinizin } \\
\text { destinasyon ve } \\
\text { işletmeden istek ve } \\
\text { beklentileri nelerdir? }\end{array}$} & Şehir temizliğine önem verilmesi & 6 & $\mathrm{~K} 1, \mathrm{~K} 4, \mathrm{~K} 5, \mathrm{~K} 11, \mathrm{~K} 14, \mathrm{~K} 15$ \\
\hline & $\begin{array}{l}\text { Turistik bölgelere ulaşımın daha kolay } \\
\text { olması ve yöresel turların arttırılması }\end{array}$ & 3 & $\mathrm{~K} 3, \mathrm{~K} 12, \mathrm{~K} 13$ \\
\hline & ----- & 2 & K9, K10 \\
\hline & Altyapı ve tesis yetersizliğinin giderilmesi & 1 & $\mathrm{~K} 7$ \\
\hline & $\begin{array}{l}\text { Doğanın korunması ve tarihi alanlara } \\
\text { bakımın arttırılması }\end{array}$ & 2 & $\mathrm{~K} 2, \mathrm{~K} 8$ \\
\hline & Misafirperverliğin arttırılmasının istenmesi & 1 & K6 \\
\hline
\end{tabular}

'Doğu Ekspresi popüler olduktan sonraki süreçte misafir profilinizdeki değişiklikler nelerdir?' sorusuna verilen yanıtlara bakıldığında işletmelerin \%40'1 tur ile gelen misafir sayısında artış yaşandığını belirtmiştir. K2 ve K7 katılımcılar misafir profillerinin genç nüfusa kaydığını ve daha çok yerli turist akını olduğunu aktarmıştır. K3 kodlu katılımcı ise misafir profillerinin yüksek standartta ve nitelikli misafirlere kaydığını belirtmiştir.

'Kars'a artan ilginin yöre halkı üzerindeki etkileri nelerdir?' sorusuna verilen yanttlar incelendiğinde işletmelerin \%80'i genel olarak ekonomilerinin olumlu yönde etkilendiğini söylemiştir. K2 kodlu işletme yöneticisi 'Turistik ürünlerde satış artışı yaşanmaya başlandı. Kadın girişimcilerin önü açılarak bu durum gitgide yaygınlık göstermeye başlamıştır. Kars'ın önceden tarım ve hayvancılık şehri olduğunu söyleyen yerliler artık şehre turizm şehri olarak bakmaktadırlar.' cevabını vermiştir. K12 kodlu işletme yönetici ise 'Yöresel özellikler açısından bakıldiğında özellikle peynir çeşitlerinde büyük bir artış yaşanmakta ve bu konu ile ilgili çalışmalar yapılmaktadır. Ekonomik olarak düşündüğümüzde ise ekonomide \%50 artış yaşanmıştır.' cevabını vermiştir. 
İşletmelere yönlendirilen 'Kars'a artan ilginin olumsuz sonuçları nelerdir?' sorusuna alınan cevaplarda; \%47'lik kısım olumsuz bir etkisinin olduğunu düşünmemektedir. Diğer işletmeler ise trenlerin aksadığını, ilin altyapısının ve tesislerin yeterli olmadığını düşünmektedir. İşletmelerin \%26'sı tarafından destinasyona artan ilgiyi esnafın firsatçılık olarak değerlendirip ahlaki olmayan davranışlar sergilediği şeklindeki olumsuzluktan bahsedilmiştir.

'Misafirlerinizin beklenti ve istekleri nelerdir?' sorusuna verilen yanıtların ağırlıklı olarak (\%40) çevre temizliğine yönelik olduğu görülmektedir. Belediyenin bu yönde daha çok çalışarak sokakları-caddeleri temizlemesi ve yıkık dökük binaların onarılması istendiği belirtilmiştir. Altyapı ve tesis yetersizliğinin giderilmesi, doğanın korunması ve tarihi alanlara bakımın arttırılması misafirlerin diğer istekleri arasında yer almaktadır.

\section{Sonuç, Tartıșma ve Öneriler}

Seyahat esnasında trendeki yolcularla, destinasyonda konaklama işletmeleriyle gerçekleştirilen ve iki aşamalı olarak yürütülen karma araştırma yönteminin kullanıldığ 1 çalışmada Doğu Ekspresi ve Kars'taki konaklama işletmelerine etkileri incelenmiştir. Doğu Ekspresi yolcularına ilişkin genel bir durum değerlendirmesi yapılmıştır. Doğu Ekspresi ile seyahat eden katılımcıların \%79'u üniversite mezunu olup, seyahatleri sırasında tur şirketi üzerinden bilet alımını gerçekleştirmiştir. Benzer şekilde Ceylan, Ceylan ve Yaman'ın (2018) çalışmasında sosyal medyanın da etkisiyle özellikle Y kuşağı arasında büyük rağbet gören Doğu Ekspresi yolculuğu için birçok tur şirketi ve seyahat acentesinin paket programlar hazırladığı aktarılmaktadır. Doğu Ekspresi’nde doluluk oranının \%100 olması sebebiyle bilet bulmakta oldukça zorlanılmaktadır. Bu duruma fiyatların uygunluk düzeyi neden olmaktadır. Bununla birlikte katılıcıların yarıdan fazlasının Kars'a gidișleri sırasında hem hız hem de Doğu Ekspresi'nde bilet bulamama durumundan dolayı havayollarını tercih ettiği dikkat çekmektedir. Katılımcıların çoğu için de Doğu Ekspresi bilet fiyatları ve Kars'taki konaklama işletmelerinin fiyatlandırma politikaları orta seviyededir. Katılımcıların \%72'si otelde konaklamayı tercih etmiştir. Ortalama konaklama süreleri 1-3 gün aralığındadır.

Destinasyon ve turizm işletmeleri tanıtım ve pazarlamasında önemli rol üstlenmiş olan sosyal medya, Doğu Ekspresi için de önemli bir tanıtım aracı olarak görülmektedir. Katılımcıların çoğu Doğu Ekspresi'ni ilk defa sosyal medyadan duymuştur. Eryılmaz ve Yücetürk'ün (2018) çalışmalarında; popüler bir sosyal medya uygulaması olan Instagramda, Doğu Ekspresi ile ilgili paylaşılan fotoğraf ve videoların diğer kullanıcıları olumlu yönde etkilediği ve onları da bu seyahati tercih etmeye ittiği sonucuna ulaşıldığı belirtmektedir. Yapılmış olan bir diğer çalışmada da (Doğan vd., 2018) gelecekte daha çok insanın sosyal medya araçlarını kullanarak bilgi/deneyimlerini paylaşacağı ve seyahat yorumları yapacağ platformların gelecekte çok daha önemli bir role sahip olacakları görüşünü desteklemektedir. Doğu Ekspresi'nin ilk kez duyulduğu yıllar incelendiğinde tanınırlığının yıllar geçtikçe hız kazandığı görülmüştür. Doğu Ekspresi'yle seyahat eden kişi sayısının artışına paralel olarak konaklama işletmelerinin de doluluk oranlarının artması, dolaylı istihdamın yaşanması gibi olumlu etkiler yaşanmaktadır. Ancak altyapının yetersiz kalması, esnafın ticaret etiğini ihlal ederek turistlere yaklaşımlarının yanlış olması gibi olumsuzluklardan bahsedilmektedir. Ulaşılan bu bilgiler ışığında turizm işletmelerine, araştırmacılara, resmi kurum ve kuruluşlara yönelik aşağıdaki öneriler sunulabilir:

- Şehrin altyap1 durumunun tekrar gözden geçirilerek Doğu Ekspresi’nin ve diğer turistik faaliyetlerin yarattığ 1 hareketliliği kaldırabilecek taşıma kapasitesine göre yeniden düzenlenmesi hem turistler hem yöre halkı hem de işletmeciler açısından fayda sağlayacaktır.

- Turizm bilincinin gerek bölge halkı gerekse turizm işletmeleri düzeyinde kazandırılması için eğitimler verilebilir ve çeşitli bilgilendirme/bilinçlendirme afişleri düzenlenebilir. 
- Şehrin üstyapı düzenlemesi konusunda turistlerin beklentileri dikkate alınarak kentsel dönüşüm konusunda gerekli çalışmalar yapılabilir.

- Turizm işletmeleri, giderek artış gösteren talebi dikkate alarak kapasite artırımı için girişimde bulunabilir.

- Doğu Ekspresi seferlerinde tren içinde çeşitli destinasyonlara, yöresel ürünlere ilişkin tanıtım broşür ve afişleri kullanılabilir.

- Kars'a ait gastronomik unsurlar belirlenip, turizm amaçlı kullanımı için çalışmalar yürütülebilir. $\mathrm{Bu}$ ürünler için festivaller düzenlenerek bu festivallere ilişkin duyurumlar yapılabilir ve konuyla ilgili Doğu Ekspresi (TCDD) ile iş birliği içinde çalışılabilir.

- Doğu Ekspresi'nin destinasyondaki yiyecek-içecek işletmelerine etkisine yönelik bir çalışma yapilabilir.

- Doğu Ekspresi yolcularının destinasyon hakkında bilgi düzeylerini belirlemeye ilişkin bir araştırma yapılması destinasyon yönetimi ve turizm sektörü açısından aydınlatıcı olabilir.

\section{Kaynaklar}

Akbulut, G. (2010). Türkiye'de demiryolu ulaşımı. Ankara: Anı Yayıncılık.

Akın, F. ve Sultanoğlu, F. (2006). 1856'dan 2006'ya Demiryollarının 150 yılı. Ankara: Demiryol-İş.

Alkheder, S. (2016). Transportation and tourism sustainability in major jordanian tourism cities. Tourism Planning \& Development, 13(3), 253-273.

As, E. (2006). Cumhuriyet dönemi ulaşım politikaları (1923-1960). Doktora Tezi, Dokuz Eylül Üniversitesi Atatürk İlkeleri ve İnkılap Tarihi Enstitüsü, İzmir.

Atalay, İ. ve Mortan, K. (1995). Türkiye bölgesel coğrafyası. İstanbul: İnkılap Kitap Evi.

Babic, O., Kalic, M., Pavkovic. G., Cangalovic, M. and Dozic, S. (2010). Heuristic approach to the airline schedule disturbances problem. Transportation Planning And Techonology, 33(3), 257-280.

Bayrak, R., Doğan, S. ve Ergun, N. (2019). Turizm pazarlaması için önemli bir pazarlama kanalı olan instagram'da nitel bir araştırma. Güncel Turizm Araştırmaları Dergisi, 3(1), 82-100.

Belobaba, P., Odoni, A. and Barnhart, C. (2016). The global airline industry. Noida: John Wiley \& Sons Yayıncilik.

Beltran Esteve, M. and Picazo Tadeo, A. (2015). Assessing environmental performance trendsm in the transport industry: eco-innovation or catching-up. Energy Economics, (51), 570-580.

Bingöl, A. (2011). Kars ve çevresinde demir çağı yerleşmeleri. Sosyal Bilimler Enstitüsü Dergisi, 8, 20-40.

Carpenter, T. T. (1994). The environmental ımpact of railways. Chishester: Wiley Yayınc1lik.

Ceylan, V., Ceylan, F. ve Yaman, M. (2018). 70 yıl sonra gelen değişim: Doğu Ekspresi yolculuğunu gastronomi turizmi kapsamında değerlendirilmesi. 1.Uluslararast Turizmde Yeni Jenerasyonlar ve Yeni Trendler Konferansl, 1-3 Kasım 2018. 
Cirit, F. (2014). Sürdürülebilir kentiçi ulaşım politikaları ve toplu taşıma sistemlerinin karşılaştırılması. Kalkınma Bakanlığı İktisadi Sektörler ve Koordinasyon Genel Müdürlüğü.

Cook, R., Yale, L. and Marqua, J., (1999). Tourism the business of travel. New Jersey: Prentice Hall Yayınevi.

Çakıcı, C. (2019). Kavramlar ve örneklerle genel turizm. Ankara: Detay Yayıncılık.

Çakmak, V. ve Altaş, A. (2018). Sosyal medya etkileşiminde tren yolculukları: Doğu Ekspresi ile ilgili youtube paylaşım videolarının analizi. Journal of Tourism And Gastronomy Studies, 6(1), 390-408.

Demir, M. ve Alım, M. (2016). Sarıkamış Bayraktepe (Cıbıltepe) kış sporları ve turizmi merkezine ait coğrafi bir değerlendirme. Marmara Coğrafya Dergisi, 33, 241-275.

Demir, M. (2017). Doğal ve beşerî özellikleriyle Kars ilindeki turizm faaliyetlerinin durumu. Marmara Coğrafya Dergisi, 35, 134-154.

Dilek, S., Kaygalak, S., Türksoy, S. ve Timur, A. (2015). Kruvaziyer turizmi: İzmir merkez liman olabilir mi? Batman Üniversitesi Yaşam Bilimleri Dergisi, 5(2), 33-56.

Doğan, A. (2014). Karayolu yük taşımacıllğı. İstanbul: Beta Yayınc1lık.

Doğan, M., Pekiner, A. ve Karaca, E. (2018). Sosyal medyanın turizm ve turist tercihlerine etkisi: Kars-Doğu Ekspresi. Seyahat ve Otel İşletmeciliği Dergisi, 15(3), 669-683.

Doğaner, S. (1996). Türkiye'de turizm ulaştırması. Coğrafya Araştırmaları Dergisi, 4, 19-45.

Doğaner, S. (1998). Türkiye ulaşım sistemleri turizm ve çevre ilişkileri. İstanbul Üniversitesi Coğrafya Dergisi, 6, 1-26.

Dursun, A. ve Erol, S. (2012). Denizyolu yük taşımacıllğı sektöründe faaliyet gösteren firmaların finansal yap1 analizi. Atatürk Üniversitesi Sosyal Bilimler Enstitüsü Dergisi, 16(1), 367-382.

Erdal, M., Güvenler, A. ve Sandalcı, K. (2009). Uluslararası demiryolu eşya taşımacılığı. Uluslararası Taşımacılık ve Lojistik Hizmet Üretenlerin Derneği, İstanbul.

Eryılmaz, B. ve Yücetürk, C. (2018). Genç turistlerin doğu ekspresi seferleri tercihlerinde ınstagram'ın rolü. Turizm ve Gastronomi Çalışmaları Dergisi, 6(4), 210-228.

Hamzaçebi, A. B. ve Yozgat, U. (2019). Turizm sektöründe alg1 yönetiminin rolü. International Journal of Management and Administration, 5(3), 51-65.

Hatipoğlu, S. ve Işık, E. S. (2015). Havayolu ulaşımında hizmet kalitesinin ölçülmesi: İç hatlarda bir uygulama. KSÜ Sosyal Bilimler Dergisi, 12(2), 293-312.

INT I. https://www.rotasenin.com/dogu-ekspresi (Erişim Tarihi: 14.03.2019).

Kozak, N., Kozak, M. ve Kozak, M. (2006). Genel turizm ilkeler ve kavramlar. Ankara: Detay Yayıncilik.

Kuyucak, F. ve Şengür, Y. (2009). Değer zinciri analizi: Havayolu işletmeleri için genel bir çerçeve. Karamanoğlu Mehmetbey Üniversitesi İ̈BF Dergisi, 11(16), 132-147. 
Kültür ve Turizm Bakanlığı. Kars İli Tarihçe. https://kars.ktb.gov.tr (Erişim Tarihi: 20.02.2019)

Mammadov, R. (2012). The importance of transportation in tourism sector. 7th Silk Road International Conference "Challenges and Opportunities of Sustainable Economic Development in Eurasian Countries", 381-386.

Öztürk, Z. ve Arıl1, V. (2009). Demiryolu mühendisliği. İstanbul.

Page, S. (2009). Tourism management. Burlington: Elsevier Yayınları.

Rodrigue, J. P. (2017). The geografhy of transport systems. New York: Routledge Yayinevi.

Saatçioğlu, C. (2011). Ulaştırma ekonomisi teori ve politika. Ankara: Gazi Kitapevi.

Saban, M. ve Güğercin, G. (2009). Deniz taşımacılığı işletmelerinde maliyetleri etkileyen faktörler ve sefer maliyetleri. Dokuz Eylül Üniversitesi Denizcilik Dergisi, 1(1), 1-16.

Şahbaz, R. ve Yüksel, S. (2008). Türkiye'de ulaştırma aracı seçiminde etkili olan etkenler ve demiryollarının rekabet edebilirliği. Elektronik Sosyal Bilimler Dergisi, 7(25), 197-211.

Türkiye Cumhuriyeti Devlet Demiryolları İşletmesi Genel Müdürlüğ̈. (2017). Demiryolu Sektör Raporu 2016.

Türkiye Makine Mühendisleri Odası Birliği. (2012). Ulaşımda demiryolu gerçeği, Oda Raporu, Yayın No: MMO/592.

Truong, N. V. ve Shimizu, T. (2016). The effect of transportation on tourism promotion: literature review on application of the computable general equilibrium (cge) on application of the computable general equilibrium (cge) model. Transportation Research Procedia, 3096-3115.

Tuna, B. (2018). Doğu ekspresi hakkında merak edilen bilgiler. Milliyet. (Erişim Tarihi: 13.03.2019).

Wright, P. H. and Dixon, K. K. (2004). Highway engineering. United States of America.

Yardımcıoğlu, F. (2013). Ulaşım hizmetleri (kamu ekonomisi perspektifi). Bursa: Dora Yayıncılık.

Yıldırım, İ. (2001). Cumhuriyet döneminde demiryolları (1923-1950). Atatürk Araştırma Merkezi, Ankara.

Yiğitbaş, A. (2014). Ani harabeleri ve Fetih cami. Akademik Tarih ve Düşünce Dergisi, 1(4), 1-5. 


\section{Extended Abstract}

\section{Introduction}

Tourism is the temporary relocation of people to places other than their normal places of work and residence, activities during their stay in these places, and facilities created to meet their needs (Cook, Yale and Marqua, 1999). Transportation, a system based on the displacement of persons or goods in time and space; decisively defined as an intermediate service needed by the society (Yardımcioğlu, 2013). In the study, the development process of Railways in the world and in Turkey was explained, the tourism potential of Kars province was evaluated and information about the Eastern Express was given. The research method was explained and the findings of the Eastern Express passengers and accommodation companies were examined under separate headings.

The Eastern Express is an express belonging to the TCDD which runs on the main line from Ankara to Kırıkkale, Kayseri, Sivas, Erzincan, Erzurum and Kars and completes approximately 1300 $\mathrm{km}$ of road in 25 hours. From a historical point of view, the extension of the Express from Ankara to Kars was realized in 1961 (Çakmak and Altaş, 2018). Recently, famous travelers ' trips to Kars attract attention. In order to grow the marketing circle and create a sound, instagram sponsors and advertisements for millions of followers and thus increases interest in the Eastern Express day by day. It is known to be particularly favoured by young people aged between 18 and 25 . With an increase of $40 \%$ compared to 2016 , the number of sleeper cars was increased to three on some flights to Kars. As a result of the increasing interest, 100\% occupancy was noted in hotels (Hamzaçebi and Yozgat, 2019). Research shows that 'cheapness' and 'safety' factors play a major role in choosing Railways today as they did in past times (Kozak, Kozak and Kozak, 2006). The seat fee is $135 \%$ more convenient than airlines and $73 \%$ cheaper than highways in the selection of the Eastern Express pulman as a means of transportation for a person who wants to go to Kars from Ankara province.

\section{Method}

The aim of the study was to determine the effect of the Eastern Express on tourism activities in Kars by analyzing the situation of the passengers travelling with the Eastern Express and a twostage research was carried out. Quantitative and qualitative research techniques were used together in the study. The study represents two separate samples in general terms. The first sample was from passengers travelling on the Eastern Express and the questionnaires collected from passengers who agreed to fill out the survey using the easyda sampling method were evaluated. Passengers staying in Kars on their way back were preferred and a survey was carried out during the trip. Due to material and temporal inadequacy, the conduct of the study at one time of the Eastern Express is evaluated among the constraints of the research. The second part of the study was the managers of accommodation companies in Kars. Semi-structured interviews with business managers; The general assessment of accommodation businesses in Kars and the impact of the Doğu Express on tourism activities in Kars were directed.

\section{Results, Discussion and Conlusion}

Survey questions were applied to Eastern Express passengers travelling from Kars to Ankara. The responses of 53 participants were analyzed. While $45 \%$ of respondents stated that they traveled 36 times a year, the proportion of those traveling 2 times and below was 36\%. When the travel objectives of the participants were examined, it was observed that the majority (91\%) travelled for tourist purposes. It was found that $62 \%$ of respondents heard the Eastern Express from social media (51\%) between 2016 and 2019.

A total of 15 accommodation companies, 2 of which are chains and 13 of which are independent, were interviewed in Kars. With the popularity of the Eastern Express, it was stated that the businesses were generally undergoing renovations and renovations. It is also mentioned that there 
has been an increase in service quality. Answers have been received that sprinkling breakfasts have been turned into open buffets and enriched. Some businesses have reported that guest profiles have shifted to the younger population and there is an influx of more domestic tourists. Some businesses have stated that their guest profiles have shifted to high standard and qualified guests.

Most of the participants heard the Eastern Express on social media for the first time. The first time that the Eastern Express was heard, it was observed that its recognition gained speed over the years. In parallel with the increase in the number of people travelling with the Eastern Express, There are positive effects such as increased occupancy rates and indirect employment. In the light of this information, the following suggestions can be made for tourism enterprises, researchers, public institutions and organizations:

* The infrastructure situation of the city will be revised and the Eastern Express and other tourist activities will benefit both tourists and local people and operators.

* Trainings can be given and various information/awareness posters can be arranged in order to gain tourism awareness at the level of both local people and tourism enterprises.

* Necessary work can be done on urban transformation by taking into account the expectations of the tourists regarding the arrangement of the superstructure of the city.

* Tourism enterprises can take steps to increase capacity by taking into account the increasing demand.

* Promotional brochures and posters related to various destinations and regional products can be used in the train on the Eastern Express flights.

* The gastronomic elements of Kars can be determined and studies can be carried out for their use for tourism purposes.

* A study can be carried out on the impact of the Eastern Express on food and beverage businesses in the destination.

* Conducting a survey to determine the level of knowledge about the destination of Eastern Express passengers can be enlightening for the destination management and tourism sector. 